\title{
A magyar keresztény terminológia bizánci rítusú szláv elemei
}

1. Bevezetés. A magyar köznyelvi szókincs idegen eredetü elemei közül a legnagyobb tételt szláv jövevényszavaink teszik ki (VERMES 1941, PAPP 1967: 521, vö. ZOLTÁN 2017a: 1), természetes tehát, hogy a szláv eredetü szavak keresztény terminológiánkban is számosak és fontosak. Elég, ha néhány alapvető terminusra utalunk: kereszt, keresztel, keresztyén (ebből később a kereszt beleértésével keresztény); apáca, apát, barát 'szerzetes', pap; pokol; szent, szentel; szerda, csütörtök, péntek, szombat; zarándok, vecsernye, zsolozsma. Ide tartozik néhány ma már föleg csak biblikus összefüggésben használt szó és szólás is: hálát ad, malaszt, nyoszolya, parázna, szövétnek.

Régi szláv jövevényszavaink tekintélyes száma arra enged következtetni, hogy ezek nem egyszerü nyelvhatár menti érintkezéssel jutottak a magyarba, hanem nagyobb számú néptömegnek a Kárpát-medence központi területein történt beolvadása útján (BALASSA 1937: 46; vö. még: BENKÖ 1997: 170, KIEFER 2010: 716). A közelmúlt jelentős külföldi kutatói közül elsősorban EvGENIJ CHELIMSKIJ (1950-2007) képviselte és támasztotta érvekkel alá azt az álláspontot, hogy a honfoglaló magyarság elsősorban nem a perifériákon a szomszédos szláv népességgel való érintkezés során, hanem a Kárpát-medence központi területein, az itt talált szláv lakosság beolvasztása folyamán vette át régi szláv jövevényszavainkat (CHELIMSKIJ 1988).

CHELIMSKIJ a honfoglaláskor a Kárpát-medencében talált szlávok nyelvéből próbálta magyarázni a magyar keresztény terminológia összes szláv elemét, teljesen feleslegesnek nyilvánítva minden olyan kísérletet, amely e halmazból megpróbálta kiválasztani azokat, amelyek a bizánci, illetve a nyugati térítés szláv nyelvi közvetítésének a nyomait viselik magukon (CHELIMSKIJ 1993).

CHELIMSKIJnek több konkrét kérdésben igazat kell adnunk: valóban nem lehet például kereszt vagy pap szavunkat a bizánci térítéssel összefüggésbe hozni csak azért, mert ezek szláv előzményei ma többnyire az ortodox szlávok nyelveire jellemzők. Ugyanakkor azonban azt sem hagyhatjuk figyelmen kívül, hogy a magyarok körében a szervezett bizánci térítés a honfoglalás után kezdődött, ${ }^{1}$ tehát a Kárpát-medencében talált szlávok nyelve mellett a bizánci misszionáriusok nyelve is hathatott a magyarra. A kimagaslóan nagy számú szláv jövevényszót a magyar nem fogadhatta be a honfoglaláskor egyszerre, a helyben talált szláv nyelvü lakosság asszimilálása időt vett igénybe, ezért a honfoglalást követő egy-két évszázadban a szláv-magyar kétnyelvüség elterjedtsége valószínűsíthető. Kézzelfogható bizonyítékai ennek az Ácsteszér, Kálsár, Lippahárs típusú tautologikus szláv-magyar helynevek (KISS 1979); a huzamosabb ideig tartó kétnyelvüségnek köszönhető a tekintélyes számú szláv mintára alkotott tükörszó is a magyarban (pl. kedd < keted, vö. óegyházi szláv vъtorъkъ 'kedd' : vъtorъ 'második', tizenegy,

${ }^{1}$ A bizánci térítés történetéről újabban 1. RÉvÉSz ÉVA munkáit (2014, 2016), ezek a korábbi szakirodalom kritikai áttekintését is tartalmazzák. 
tizenkettő stb., vö. óegyházi szláv edinъ na desęte, dъva na desęte stb.); ide tartozik valószínüleg a fog ige használata is a jövő idő segédigéjeként (ZOLTÁN 2018). (A szláv mintájú tükörszavakról részletesen 1. KISs 1976; a tükörszavak és a kétnyelvüség összefüggéséről szláv-magyar viszonylatban 1. még H. TóTH 2000: 12. A jövevényszavakról és a tükörszavakról a magyarban újabban 1. ZOLTÁN-JANURIK 2018.)

2. A bizánci térítés nyelve. Nem véletlen, hogy a bizánci egyház a magyarok között végzendő térítő munkára szlávul tudó misszionáriusokat küldött. Amint GYÖRFFY GYÖRGY fogalmazott: „Mivel a görög püspök Magyarországon a görög nyelvvel semmit sem ért el, viszont a szlávokkal régóta szimbiózisban élő magyarok legtöbbje tudott valamit szláv nyelven, a görög püspök bolgár-szláv tolmácsokkal kezdhette el az igemagyarázatot" (MTört. I/l: 684. Vö. újabban: KoRDÉ 2018: 14-15, KOROMPAY 2019). Szláv-görög kétnyelvű papokat Bizáncban nem volt nehéz találni, tömegesen éltek ekkor szlávok Macedóniában. Innen, Szalonikiből került ki a 9. század második felében Pannóniában is megfordult testvérpár, a szláv írásbeliséget és liturgikus nyelvet megalkotó Konstantín-Cirill és Metód is, ilyen görög-szláv kétnyelvü bizánci alattvalók lehettek a 10. század végén a keleti szlávok térítésére induló misszionáriusok is, akik nemcsak az óegyházi szláv liturgikus nyelvet vitték magukkal Kijevbe, hanem macedóniai szláv dialektusuk néhány szavát is meghonosították a keleti szlávban (STRACHOV 1988: 84, 2003: 106-107).

CHELIMSKIJjel általában egyetértve abban, hogy a magyaroknak a honfoglalást követően ${ }^{2}$ felesleges lett volna a szomszédos szláv nyelvekből átvenni jövevényszavakat, amikor itt, az ország belsejében is volt szláv nyelvü népesség, mégpedig olyan, amelynek körében már jóval a magyarok bejövetele előtt folyt térítés, nem hagyhatjuk figyelmen kívül, hogy a keresztény tanok intézményes terjesztése során a hittérítők anyanyelvjárása is hathatott a magyarra, mégpedig azokban az esetekben is, amikor a szláv nyelvek nagyfokú hasonlósága miatt ezt bizonyítani nem tudjuk (barát, szent, szentel, kereszt, keresztel, pap stb.). Kizárni tehát nem lehet, hogy az elvben a hazai (CHELIMSKIJ terminológiájában: a pannóniai) szlávból is átvehető egyházi müszavak meghonosításában a macedóniai szláv dialektust beszélő bizánci térítők is közreműködtek.

3. A szláv közvetítés nyelvi öröksége. Úgy gondolom, hogy CHELIMSKIJ hiperkritikus felfogásával szemben is védhető, hogy a bizánci misszió nyomait örzik nyelvünkben az egyházi terminológia korai szláv elemei közül azok, amelyek bizonyíthatóan balkáni eredetűek. Ezek közé tartoznak véleményem szerint a karácsony és a pitvar szavak, továbbá a hálát ad kifejezés.

A magyar karácsony szláv eredete a tudományos szakirodalomban általánosan elfogadott, ${ }^{3}$ viszont az alapjául szolgáló délszláv, esetleg szlovák nyelvjárási

${ }^{2}$ A szakirodalomban sokszor felvetik, hogy a magyarok már a honfoglalás előtt is megismerkedhettek egyes keresztény fogalmakkal, és a kereszt szót már Levédiában átvehették az ókeletiszlávból. Ennek a hipotézisnek azonban nyelvészeti alapja nincs, bizonyítani nem lehet (vö. ZoLTÁN 2017b).

${ }^{3}$ Nem így dilettáns körökben, ahol több más légböl kapott ötlet között jelenleg a kerecsen 'egyfajta sólyom' szóval való azonosítása dívik, mégpedig a hamis Kassai Kódexre hivatkozva koholt karácsonyi sólyomröptetés „ősi szokására” hivatkozva (vö. legújabban: WOHLFART 2018). 
*kračunъ etimológiája erősen vitatott. (A magyar karácsony és szláv elözményének etimológiájáról részletesen 1. ZOLTÁN 1991 és 2005, 45-51, ezért itt csak a fontosabb vitapontokra térek ki.) A hazai kutatók minden nehézség ellenére kitartanak a mellett az eredetileg MELICH JÁNOStól származó etimológia mellett, amely szerint a szó szláv alapon magyarázható: *korkb 'láb; lépés' > *korčiti 'lépni' > *korčun 'lépő, átlépő, forduló (nap)', vagyis 'téli napforduló' (MELICH 1908: 178). Ezt több tekintélyes szláv etimológus is elfogadta (vö. EtSiSJaz. 11: 56-58) annak ellenére, hogy szóképzési szempontból ez a levezetés hibás (az -unъ képző előtt a régi adatokban nem volt palatalizáció, vö. óegyházi szláv běžati 'fut' : běgunъ 'szökevény', orosz кричать 'kiabál' : крикун 'nagyhangú 〈ember〉', tehát egy *korčiti ige -unъ képzős származéka szabályosan nem *korčunz, hanem *korkunъ lett volna; ráadásul az -unъ képző sem volt produktív az ősszlávban, vö. ZOLTÁN 1993). Ezzel a nehézséggel KNIEZSA IsTVÁN (1955: 254) és KISS LAJOS (1957) is tisztában voltak, de nem vetették el MELICH etimológiáját, mert a többi közkézen forgó etimológia még ennél is gyengébbnek tűnt. ${ }^{4}$ Etimológiai szótáraink is ezt az verziót fogadják el, a szláv szóképzési anomáliákról immár szót sem ejtve (TESz. 2: 371-372, EWUng. 2: 693, ESz. 379). Időközben azonban már 1961-ben megjelent EQREM ÇABEJ (1961) szófejtése a román crăciún 'karácsony’ eredetéről. Ö ugyan a román szó forrását vélte felfedezni az albánban, alapötlete azonban a szláv *korčun s 'téli napforduló' szóra alkalmazható. ÇABEJ abból indult ki, hogy egyrészt az egész albán nyelvterületen létezik a (geg) kërcû, kërcuni, (toszk) kërcú, kërcúri (a tỏ eredetileg kërcún- < óalbán karcun-) 'tönk, rönk, tuskó' jelentésü, indoeurópai eredetü főnév, másrészt a balkáni népeknél igen elterjedt a karácsonyi tuskó- vagy rönkégetés szokása (szerb badnjak, bg. бъдник). Amint azonban azt később AGNIJA DeSNICKAJA bebizonyította, nem a román crăciún, hanem a délszláv *kračunb származik az albánból, a román szó a délszlávból lett átvéve (DESNICKAJA 1976: 43-46; vö. OREL 1998: 181).5 A szlávba a téli napforduló pogány ünnepének „föszereplőjeként” került át az eredetileg 'tuskó' jelentésủ albán szó (immár mintegy 'a tuskó ünnepe'), majd a később a téli napfordulóhoz időben közel álló keresztény ünnep neve lett. A MELICH-féle etimológiát követő szerzők teljesen figyelmen kívül hagyják, hogy a fával kapcsolatos jelentések megvannak több szláv nyelvben, így a szerbhorvát kràčūn 'retesz' eredetileg 'az istállóajtó bereteszelésére szolgáló fagerendá'-t jelentett (SCHÜTZ 1966); korábban ez a szó 'karácsonyi tuskó'-t is jelenthetett (SKOK 2: 175). Ide sorolhatók még: ukrán nyelvjárási крачýн 'nagy tölgyfatuskó' (JAVORNYC'KYJ 1920: 391) ${ }^{6}$ és a fehérorosz карачýн 'görbe és ágas fa' (ĖSBM. 4: 265). Mindezek a jelentések megerősítik, hogy a szó alapja egy 'farönk, tönk, tuskó' jelentésű szó lehetett, de mint láttuk, a román közvetítés csak az ukrán és szlovák nyelvjárási,

${ }^{4}$ A szakirodalomban felmerült neolatin etimológiák tarthatatlanságáról 1. KERĎO 2002.

${ }^{5}$ A délszláv *kračunъ szabályos reflexe egy óalbán *karcun- alaknak, vö. óegyházi szláv brada 'szakáll' < összláv *bărdā; a č > c hanghelyettesítés azzal magyarázható, hogy a szláv-albán nyelvi érintkezések kezdetén a szlávban még nem volt $c$.

${ }^{6}$ Hangalakja miatt a román crăciún-ból, amelynek 'karácsony' mellett 'furkósbot' jelentése is van (GÁLDI 1958: 12), ezért nem indokolt elválasztani a románnal érintkező ukrán nyelvjárások крачу́н 'karácsonyi kalács' szavától, ahogy azt az ESUM. (3: 80 крачун2 címszó alatt) teszi. 
a keresztény 'karácsony' ünnepéhez kapcsolódó alakok, illetve az ukrán 'tölgyfatuskó' jelentésű крачýн esetében lehetséges, sőt nagyon valószínü; a pogány kori 'téli napforduló' ünnepéhez kapcsolódó mitológiai jelentéseket - mivel ezek a románból teljesen hiányoznak - a román szó a szláv felé nem közvetíthette. Ezek a mitológiai jelentések - orosz nyelvjárási карачýн 'hirtelen, váratlan halál', 'gonosz szellem, ördög, démon', fehérorosz карачýн 'idő előtti halál', 'halál, vég', 'föld alatt élő király, mesebeli fagyisten, aki halált hoz' - a tuskóégetés pogány kori szertartásából érthetők meg: a fa gyökerei között rejtőző kígyó, a halált hozó gonosz szellem legyőzése a tuskó elégetésével, így az élet újjászületése, ezek a jelentések pedig csak az oroszban és a fehéroroszban maradtak fenn (MNM 1: 150 бадняк és 1: 623 карачун címszó alatt, vö. ZOLTÁN 2005b).

A magyarban azonban ezeknek a mitológiai jelentéseknek nyoma sincs, de hiányzanak a fával kapcsolatos jelentések is. Hasonló a helyzet a bolgár nyelvjárásokban is, itt az eredetileg a téli napfordulóhoz kapcsolódó szóban a 'napforduló' jelentés került előtérbe, így ott a крачýн 'egyes vidékeken a nyári, másutt a téli napfordulóhoz kapcsolódó népi ünnep, néhol június 8-21. között, másutt karácsony vigíliája' jelentésekben fordul elő (BER. 2: 726-727). Olyan déli szláv nyelvjárást, ahol a magyarhoz hasonlóan a крачун a nagy keresztény ünnepen kívül mást nem jelent, az albániai Korçë és a görögországi Kasztoría környékén találunk (BalkMac. 16. sz. térkép). Mivel a karácsony szó a magyarba eleve a nagy keresztény ünnep elnevezéseként került át (legalábbis semmi nyoma annak, hogy hozott volna valamit is magával egykori pogány jelentéseiből), csakis olyan szláv nyelvjárás lehetett az átadó, amelyben már végbement a 'téli napforduló' > 'karácsony' jelentésátvitel; ilyen szláv nyelvjárások pedig, mint láttuk, egyértelmüen csak a görög-albán-szláv nyelvhatár vidékén mutathatók ki. Ezzel tökéletesen egybevág az is, hogy ünnepnévként a rom. crăciún sem jelent mást, mint a keresztény 'karácsony'-t; a román egyház ugyanis a középkorban az ohridi püspökség alá tartozott (vö. KNIEZSA 1941: 31), vagyis a román egyházi terminológiára is ugyanez a szláv nyelvjárásvidék lehetett a legnagyobb hatással.

A déli szláv kračun albán etimológiájának az elfogadása azt is jelenti, hogy KNIEZSA ISTVÁN (1955: 254: „Úgy látszik, hogy a honfoglaláselötti szlávságnál lehetett elterjedve") és EvGENIJ CHELIMSKIJ (1993: 54) véleményével ellentétben nem lehet a Kárpát-medencei szlávok öröksége nyelvünkben, így nem tartozott a szláv szubsztrátumhoz a magyarban, hanem a Balkánról ,importálták” elődeink. Ennek legkézenfekvőbb közvetítői azok a macedóniai szláv nyelvjárást beszélő bizánci hittérítők lehettek, akiknek a nyelvében ez a kračunъ szó jelentette Jézus születésének ünnepét, nem pedig a Szent Cirill és Metód által görög mintára megalkotott óegyházi szláv roždbstvo (tkp. 'születés'). Tehát félreértésen alapul az az újabb etimológiai szótárainkban megfogalmazott vélekedés, hogy a karácsony „a magyarba a keleti egyház múszavaként került a Balkánról" (ESz. 379; hasonlóan EWUng. 2: 693, ÚESz. 1: [916]). A kračunъ sosem volt a bizánci rítusú szlávoknál egyházi müszó, csak éppen a bizánci misszió tagjai terjesztették el a magyarokkal érintkezve; egyházi terminus a magyarban lett, ami azért figyelemreméltó, mert a későbbi nyugati térítés nem ,írta felül”, nem szorították ki a 'születés' jelentésü latin (Dies Christi Natalis, festum Nativitatis Domini) és neolatin (olasz 
natale, francia noël) vagy a 'szent éjszaka' típusú német (Weihnachten) minták, mint a nyugati térítés által érintett más kelet-közép-európai nyelvekben (vö. pl. lengyel Boże Narodzenie tkp. 'Isten születése', illetve a német-szláv hibrid cseh vánoce, szlovák vianoce).

Hasonlóképpen nyilván még a nyugati térítés elött rögzült a magyarban a hálát ad 'megköszön' kifejezés, amely szintén ellenállt a latin gracias ago mintájának. Már MELICH JÁNOS felfigyelt arra, hogy „valahányszor a mi legrégibb bibliafordításunkban halat vagy halalatot aduan [...] fordul elö, az óbolgár evangéliumokban [...] kivétel nélkül chvala vъzdati [...] fordul elö [...]”. Ennek ellenére MELICH fejtegetésének célja „valószínüvé tenni, hogy a hála és hálát adni róm. kath., még pedig szlovén átvétel nyelvünkben." Fő kifogása az óbolgárból való eredeztetéssel szemben az, hogy az óbolgár chvalȚvozdati jelentése 'hálát össze- vagy feladni’, a magyar hálát adni azonban csupán egy szláv „chválu vagy hválu dati (és nem vbzdati) kifejezésnek felel meg. Ilyen kifejezés a róm. kath. népek közül a kaj-horvátban és a szlovénban fordul elö" (MELICH 1903-1905, I/2: 262-264). Ez utóbbi érvvel szemben KNIEZSA ISTVÁN joggal jegyzi meg, „hogy a m[agyar] hálát adni pontos mása csak itt van, nem sokat mond, mert fordítva, itt, ti. a kaj-h[orvát]ban lehet magyar eredetü is". Kevésbé indokolt KNIEZSA kétkedése abban, hogy a magyar hála szó és a hálát ad kifejezés a keresztény terminológiába tartozott volna (KNIEZSA 1955: 209-210), hiszen minden magyar nyelvtörténeti adat és a mai nyelvhasználat is arról tanúskodik, hogy a hálát ad 'köszönetet mond' kifejezés elsősorban az egyházi nyelvet jellemzi.

A TESz. KNIEZSA jogos ellenvetését nem veszi figyelembe, hanem MELICH nyomán arra az álláspontra helyezkedik, hogy a magyarba egy szerbhorvát vagy szlovén régi *chvala kerülhetett át. A szerzők azzal érvelnek, hogy a kaj-horvátban és a szlovénben a magyar hálát ad kifejezésnek is pontos mása van (TESz. 2: 31; újabb etimológiai szótáraink - EWUng. 1: 568, ESz. 281, ÚESz. 1: [678] csak a hála főnevet tárgyalják). Figyelmen kívül marad eközben az a tény, hogy a magyar hálát ad kifejezés lényegesen korábbról adatolható, mint az idézett kajhorvát és szlovén források, márpedig szóföldrajzi és müvelődéstörténeti okokból e nyelvekben a magyarról való tükörfordítás lehetőségével mindig számolni kell.

MELICH idézett fejtegetésével szemben azonban az a legfőbb kifogás hozható fel, hogy ha a hálát ad kifejezés valamely latin rítusú délszláv nyelv keresztény terminológiájából származnék, akkor meg kellene találni a kaj-horvát hvalu dati vagy a szlovén hvalo dati latin forrását; erre MELICH érthetően kísérletet sem tesz, hiszen a Vulgatában a szóba jöhető helyeken a gratias ago kifejezés fordul elö, amely nem felel meg sem a magyar kifejezésnek, sem a MELICH szerint a magyar kifejezés mintájául szolgáló kaj-horvát vagy szlovén kifejezésnek. Véleményem szerint ezért a magyar hálát ad kifejezés kaj-horvát vagy szlovén etimológiája elvetendő, mihelyt bebizonyosodik vagy valószínüsíthető a hálát ad kifejezés bizánci rítusú szláv eredete, és elfogadható magyarázat születik az ószláv chvalo vъzda(ja)ti eredetére (a részletekre vonatkozóan l. ZOLTÁn 1987 és 2005, 95-102).

Az ősszláv *chvala eredeti jelentése 'dicséret' volt, a 'köszönet' jelentés másodlagos és csak néhány délszláv nyelvben van meg: az ószlávon kívül a macedónban (фала-csak 'köszönet', RMJ. 3: 460), a szerbhorvátban és a szlovénben 
(mindkét nyelvben hvála - 'dicséret' és 'köszönet', EtSISJaz. 8: 118-119; vö. KNIEZSA 1955: 209, TESz. 2: 31). Feltünő, hogy a mai bolgárban - nyelvjárási szinten is - csak a 'dicséret; dicsekvés' jelentésben van meg a szó (irodalmi хвалá, a nyelvjárásokban фалá is, EtSISJaz. 8: 118, vö. GEROV 5: 491). Azokban a szláv nyelvekben, ahol az említetteken kívül a régiségben a szó 'dicséret' mellett 'köszönet' jelentésben is felbukkan (ócseh, ólengyel; óorosz, óukrán), a 'köszönet' jelentés kizárólag egyházi értelemben volt használatos, és ilyen értelmű használata végső soron az óegyházi szlávra megy vissza, amely befolyásolta az ócseh egyházi terminológiát és ennek közvetítésével később az ólengyelt is, a keleti szláv egyházi terminológia pedig közismert módon egyenesen az óegyházi szlávból származik az egész egyházi nyelvvel együtt.

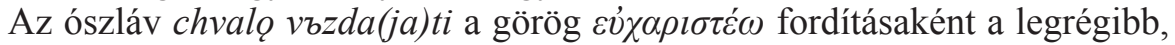
legarchaikusabb, glagolita betükkel írt, macedóniai eredetủ óegyházi szláv evangéliumfordításokat jellemzi, míg a kelet-bolgár nyelvterületen szüksége támadt

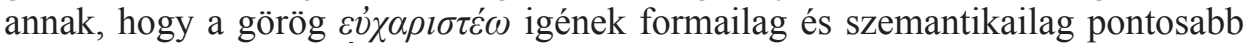
megfelelőt találjanak. Így jött létre a 11. századi kelet-bolgár Codex Suprasliensis óta adatolható blagodariti ige (vö. SJS. 1: 95: blagodarȚ ti o[tb]če jako sly a mene, míg Jn. XI, 41 a többi kódexben: o[tb]če chvalȚ tebg vъzdajṬ), amely később az

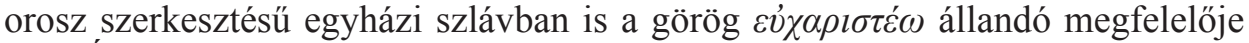
lesz. Úgy látszik tehát, hogy a mai eltérés a bolgár és a macedón szó jelentésében ('dicséret' : 'köszönet') régi keletü, már a 10-11. században is megvolt.

Az óegyházi szláv chvalo vbzda(ja)ti és görög (valamint latin és gót) megfelelőjének viszonyát MOLNÁR NÁNDOR vizsgálta meg részletesebben. A szerző véleménye szerint az a legvalószínübb, hogy az óegyházi szláv kifejezés a szláv

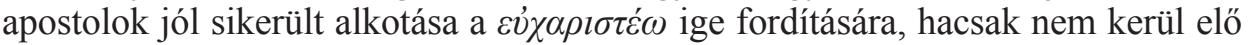
olyan görög szöveg, amely az ószlávnak pontosabban megfelelö összetett kifejezést használ (MOLNÁR 1985: 20). Volt azonban a görögben egy olyan kifejezés, amely nem fordul ugyan elö az evangéliumokban, de mind jelentése, mind pedig szerkezete tökéletesen megfelel az óegyházi szláv chvalo vbzda(ja)ti kifejezésnek: $\chi \alpha ́ \rho t v$ $\dot{\alpha} \pi \circ \delta i \delta \omega \mu l$ 'köszönetet mond, megköszön, hálával viseltetik' (SOLTÉSZ-SZINYEI 1975: 716, vö. DVORECKIJ 1: 200), amely a többek között 'köszönet, hála' jelentésü

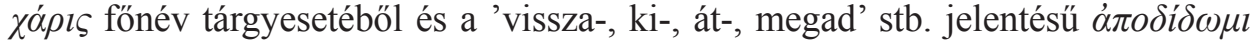
igéből áll. Véleményünk szerint az a körülmény, hogy Cirill és Metód nem alkottak tükörszót a görög $\varepsilon \dot{\gamma} \chi \alpha \rho \imath \sigma \tau \varepsilon \dot{c} \omega$ mintájára, azzal magyarázható a legkézenfekvőbben, hogy erre nem volt szükség, mivel az általuk ismert Szaloniki környéki szláv

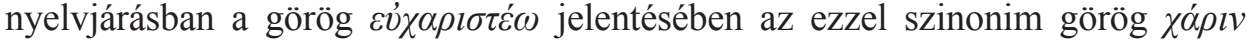
$\dot{\alpha} \pi \circ \delta i \delta \omega \mu \imath$ kifejezés spontánul, a tömeges méretü görög-szláv kétnyelvüség körülményei közepette kialakult chvalo vъzda(ja)ti tükörkifejezése volt használatban. Ezzel okafogyottá válik CHELIMSKIJ (1993: 53) ellenvetése, miszerint az óegyházi

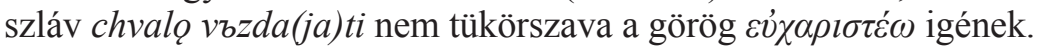

Visszatérve a magyar hálát ad kifejezés eredetének a problematikájára, MELICH JÁNOSnak a bevezetőben idézett okfejtésével szemben le kell szögeznünk, hogy míg a katolikus horvátok és szlovének hválu dati, illetve hválo dati kifejezése a latinból nem eredeztethetö, ellenben természetes módon származhat tükörfordítással a magyarból, addig az ószláv chvalo vbzda(ja)ti jól megmagya- 
rázható a görögböl. Véleményünk szerint ez a körülmény határozottan arra mutat, hogy a hálát ad kifejezés a magyarban nem latin, hanem bizánci ritusú szláv nyelvböl származik. Figyelembe véve a magyar hálát ad kifejezés régiségét, és azt a tényt, hogy a latin gratias ago kifejezéssel való több évszázados konfrontálódás ellenére a fordítók felekezeti hovatartozásától függetlenül mind a mai napig nem szorult ki a magyar egyházi nyelvböl, arra a következtetésre kell jutnunk, hogy ez a kifejezés már jóval a nyelvemlékekben való felbukkanása előtt a magyar keresztény terminológia szerves része volt. (A latin hatásnak tett engedmény nyilván a hálákat ad a Károli Gáspár-féle fordításban a többes számú latin gratias mintájára.) Nem lehet figyelmen kívül hagyni azt a körülményt sem, hogy a hálát ad kifejezés az evangéliumok néhány rendkívül gyakran idézett helyén is előfordul, tehát már a hittérítés bizonyos elemi fokán is meg kellett lennie. Ugyanakkor jellegénél fogva nem tartozik a kereszténység külső jegyei közé, amelyek elnevezésével a magyarok elvben már előbb is megismerkedhettek, mint a kereszténység felvétele (pl. kereszt, vö. MORAVCSIK 1938: 211-212). Márpedig ha egy ilyen kifejezés nyelvi okokból nem hozható összefüggésbe a nyugati térítéssel, akkor nem marad más megoldás, mint az, hogy a szóban forgó kifejezés még az azt megelőző - szláv nyelvi közvetítésü - bizánci térítés során honosodott meg nyelvünkben.

Végül a pitvar szót kell megemlíteni, mely ma a népi építészet, valamint az anatómia müszava (és nyilván ezért nem tárgyalja CHELIMSKIJ az egyházi terminológia részeként), de első előfordulása az 1300 körüli Leuveni glosszákban (pulkul pituaranak fugliabeleul) határozottan arra mutat, hogy dokumentálhatóan bibliai kontextusban használták először 'a pokol tornáca' jelentésủ szókapcsolatban (KNIEZSA 1955: 425; TESz. 3: 217). A magyar pitvar a szláv pritvorb átvétele, s ez a szláv szó csak a Balkánról jöhetett, tudniillik csak a bizánci rítusú szlávoknál fordul elö, és ott az 'ortodox templom elöcsarnoká'-t jelenti. Első pillantásra a pritvoriti 'hozzátesz, hozzáfüz' ige főnévi származékának látszik, ráadásul az ortodox templom előcsarnoka mintegy oda van ragasztva a tulajdonképpeni templomhoz, azonban az óegyházi szlávban a pritvorb mellett pretorb is van (SJS 3: 315), ami arra mutat, hogy a pritvorz népetimológiás átformálása csu-

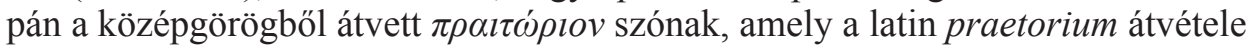
(KNIEZSA 1955: 425-426; TESz. 3: 217-218, EWUng. 2: 1169-1170). A magyar szó kétségtelenül a népnyelvi átvételnek tekinthető pritvorb átvétele, amely tehát az óegyházi szláv macedóniai nyelvjárási szubsztrátumához tartozott, mert különben aligha lett volna kitéve népetimológiás ,értelmesítésnek”. Ez is egy olyan szó tehát, amelyet a bizánci térítők terjeszthettek el, de semmiképpen sem tartozhatott a Kárpát-medencei szlávok szókincsébe (vö. ZOLTÁN 2015).

4. Kitekintés. A pitvar később világi építmények (királyi palota, majd egyszerü lakóház) előcsarnoka lett a magyarban, míg végül a parasztház részeként rögzült a köznyelvben, ahonnan a 19. század első felében beemelték az anatómiai terminológiába a latin atrium magyarítására. Először Bugát Pálnál fordul elő: szivpitvarok (1828, 1. VARGA 2015: 208). A népi építészeti terminusként lassan feledésbe merülő szó ennek köszönhetően marad fenn ma is, csak egészen más közegben. A karácsony a vallási ünnep szekularizálódása folytán világi ünnep 
is lett, így ma már nem csak keresztény terminus; a hálát ad azonban ma is ôrzi biblikus hangulatát. Mint említettük, a magyar nyelv keresztény terminológiájának további elemeit is terjeszthették a bizánci térítők, de ez a három szó eredete, története és föleg a szláv nyelvekben nyomon követhető elötörténete miatt nagy biztonsággal köthető a Szent István előtti bizánci térítéshez.

Kulcsszók: etimológia, szláv jövevényszavak, bizánci térítés.

\section{Hivatkozott irodalom}

BALASSA JózSEF 1937. A magyar nyelv életrajza. Renaissance, Budapest.

BalkMac. = KONESKI, BLAŽE - VIDOESKI, BOŽIDAR - JAŠAR-NASTEVA, OLIVERA, Distribution des balkanismes en macédonien. Univerzitetska pečatnica, Skopje, 1966.

BENKŐ LORÁND 1997. A honfoglaló magyarság nyelvi viszonyai és ami ezekből következik. In: KovÁCs LÁsZló - VeszPréMY LÁszLÓ szerk., Honfoglalás és nyelvészet. Balassi Kiadó, Budapest. 163-176.

BER. = Български етимологичен речник 1-8 (a-фя̀калка). Ред. В. И. ГЕОРГИЕВ, В. И. (később:) ДУРИДАНОВ, И., РАЧЕВА, М., ТОДОРОВ, Т. А. БАН, София, 1971-2017. ÇABEJ, EQREM 1961. Crăciun. Studii şi Cercetări Lingvistice 12: 313-317.

CHELIMSKIJ 1988 = ХЕлимСКий, Е. А. 1988. Венгерский язык как источник для праславянской реконструкции и реконструкции славянского языка Паннонии. In: Толстой, Н. И. ред., Славянское языкознание: Х Международный съезд славистов, София, сентябрь 1988 г., Доклады советской делегащии. Наука, Москва. 347-368. [Új kiadása: CHELIMSKIJ 2000: 418-434.]

CHeLIMSKIJ 1993 = Хелимский, Е. А. Ранняя славянская христианская терминология в венгерском языке. In: Толстой, Н. И. ред., Славянское языкознание. XI Международный съезд славистов, Братислава, сентябрь 1993 г., Доклады российской делегаиии. Наука, Москва. 46-64. [Új kiadása: CHELIMSKIJ 2000: 436-451.]

CHELIMSKIJ 2000 = Хелимский, Е. А. 2000. Компаративистика, уралистика: Лекции и статьи. Языки славянской культуры, Москва.

DESNICKAJA 1976 = ДЕСНИЦКАЯ, А. В. 1976. О некоторых вопросах балканистики в связи с изучением карпатского лингвистического ареала. Bопросы языкознания 1976/3: 35-46.

DVORECKIJ 1958 = Древнегреческо-русский словарь 1-2. Составил ДвоРецКИй, И. Х. Государственное издательство иностранных и национальных словарей, Москва. ÈSBM. = Этыммалагічны слоўнік беларускай мовы 1-14 (А-Т). Рэд. МАРТЫНАў, В. У. (később:) Цыхун, Г. А. Навука і тэхніка, Мінск, 1978-2017.

ESUM. = Етимологічний словник украйнської мови 1-6. Гол. ред. МЕльничук, О. С. Наукова Думка, Київ, 1982-2012.

EtSISJaz. = Этимологический словарь славянских языков: Общеславянский лексический фонд 1-41 (*a- *pažьnъ [jb]). Ред. ТруьАчев, О. Н. еtс. Наука, Москва, 1974-2018.

ESz. = Etimológiai szótár. Magyar szavak és toldalékok eredete. Főszerk. ZAICZ GÁBOR. Tinta, Budapest, 2006. 
EWUng. = Etymologisches Wörterbuch des Ungarischen 1-3. Hrsg. BENKÖ, LORÁND. Akadémiai Kiadó, Budapest, 1993-1997.

GÁLDI LÁSZLÓ 1958. Kniezsa István: A magyar nyelv szláv jövevényszavai. I. kötet. (Budapest, 1955. Akadémiai Kiadó. 1043 lap). [Ismertetés.] Magyar Nyelv 54: 1-13.

Gerov = ГеРОвъ, Н., Ръъчник, на блъгарскый языкъ съ тлькувание речи-ты на блъгарскы и на русскы 1-5. Съгласие, Пловдивъ, 1895-1904.

JAVORNYC'KYJ 1920 = ЯвоРНИцьКИй, Д. I. 1920. Словник украӥнської мови 1 (А-К). Слово, Катеринослав, 1920.

KERĎO, JÁN 2002. Je kračún latinsko-románskeho pôvodu? Slavica Slovaca 37/2: 144147.

KIEFER FERENC 2010. Hungarian. Revue Belge de Philologie et d'Histoire 88/3: 715-739. https://doi.org/10.3406/rbph.2010.7801

KISS LAJOS 1957: Karácsony szavunk östörténetéhez. Magyar Nyelvőr 81: 247-251.

KISS LAJOS 1976. Szláv tükörszók és tükörjelentések a magyarban. Nyelvtudományi Értekezések 92. Akadémiai Kiadó, Budapest.

KISS LAJOS 1979. Tautologische slawisch-ungarische Mischnamen in der ungarländischen Toponymie. Studia Slavica Hungarica 25: 231-239.

KNIEZSA ISTVÁN 1941. Erdély a honfoglalás korában és a magyarság megtelepedése. In: MÁlyUSz ElemÉR szerk., Erdély és népei. Franklin, Budapest. 19-34.

KNIEZSA IsTVÁN 1955. A magyar nyelv szláv jövevényszavai. I/1-2. Akadémiai Kiadó, Budapest.

KORDÉ ZOLTÁN 2018. Idegennyelv-tudás a 9-10. századi magyarságnál. Acta Universitatis Scientiarum Szegediensis, Acta Historica 143: 5-21.

KOROMPAY KLÁRA 2019. Ómagyar szókészlettani és jelentéstani kérdések az Apor-kódex alapján: lélek, szellet, Szentlélek. In: ForGÁCs TAMÁS - NÉMETH MIKLÓS - SINKOVICS BALÁZS szerk., A nyelvtörténeti kutatások újabb eredményei 10. SZTE BTK Magyar Nyelvészeti Tanszék, Szeged. 245-257.

MELICH JÁNOS 1903-1905. Szláv jövevényszavaink I/1-2. [Franklin], Budapest.

MELICH JÁNOS 1908. Karácsony. Magyar Nyelvőr 37: 177-178.

MNM. = Mифы народов мира 1-2. Ред. ТОКАРЕВ, А. С. 2-е изд. Советская Энциклопедия, Москва, 1987-1988.

Molnár, NÁNDOR 1985. The Calques of Greek Origin in the Most Ancient Old Slavic Gospel Texts. Akadémiai Kiadó, Budapest.

MORAVCSIK GYULA 1938. A honfoglalás előtti magyarság és a kereszténység. In: SERÉDI JuSZTINIÁN szerk., Szent István Emlékkönyv MTA, Budapest. 1: 173-212.

MTört. I/1-2. = Magyarország története I/1-2. köt. Elözmények és magyar történet 1242ig. Főszerk. SzÉKelY GYÖRGY. Akadémiai Kiadó, Budapest, 1984.

OREL, VladimIR 1998. Albanian Etymological Dictionary. Brill, Leiden-Boston-Köln.

PAPP FERENC 1967. A magyar szókincs gépi feldolgozásának egyes eredményei és további problémái. In: IMRE SAMU - SZATHMÁRI ISTVÁN szerk., A magyar nyelv története és rendszere. A debreceni nemzetközi nyelvészkongresszus elöadásai (1966.augusztus 24-28.). Nyelvtudományi Értekezések 58. Akadémiai Kiadó, Budapest. 518-522.

RÉVÉSZ ÉVA 2014. „Turkia” keleti keresztény főpapjai az első ezredforduló magyar történelmében. Belvedere Meridionale 36/1: 7-22. https://doi.org/10.14232/belv.2020.1.4 
RÉVÉSz ÉVA 2016. A keleti kereszténység a kora Árpád-korban. In: MENYHÁRT KRISZTINA - DUDÁS MÁRIA szerk., Magyarország és a keleti kereszténység - templomok, kultuszok, nyelvemlékek. Bolgár Kulturális Fórum, Budapest. 19-33.

RMJ. = Речник на македонскиот јазик со српскохрватски толкувана 1-3. Ред. КОНЕСКИ, БЛАЖЕ. Институт за македонски јазик, Скопје, 1961-1966.

SCHÜTZ, JOSEPH 1966. Der Rumänismus crăciun 'Weihnachten' im Slavischen. In: Schmaus, AloIs Hrsg. Beiträge zur Südosteuropa-Forschung. Anlässlich des I. Internationalen Balkanologenkongresses in Sofia 26. VIII. - 1. IX. 1966. Trofenik, München. 35-40.

SJS. = Slovník jazyka staroslověnského - Lexicon linguae palaeoslovenicae 1-4. Hlavní red. KuRZ, Josef (később:) HAuPTOVÁ, ZoE. Academia/Euroslavica, Praha, 19661997.

SKOK, PETAR, Etimologijski rječnik hrvatskoga ili srpskoga jezika 1-4. JAZU, Zagreb, 1971-1974.

SOLTÉSZ FERENC - SZINYEI ENDRE 1875. Görög-magyar szótár. Második újonnan átdolgozott és bővített kiadás. Ref. Főiskola, Sárospatak. [Reprint: Könyvértékesítő Vállalat, Budapest, 1984.]

STRACHOV 1988 = СТРАХOВ, А. Б. 1988. Слова с корнем благ-/блаж- с отрицательными значениями в восточнославянских диалектах (К проблеме влияния славяновизантийского миссионерства на язык и культуру Древней Руси). International Journal of Slavic Linguistics and Poetics 37: 73-114.

STRACHOV 2003 = СТРAXOВ, А. Б. 2003. Ночь перед Рождеством: народное христианство и рождественская обрядность на Западе и у славян. Palaeoslavica XI. Supplementum 1. Palaeoslavica, Cambridge (Mass.).

TESz. = A magyar nyelv történeti-etimológiai szótára 1-4. Főszerk. BENKÖ LORÁND. Akadémiai Kiadó, Budapest, 1967-1984.

H. Tóth IMrE 2000. Magyar-szláv kapcsolatok a 9-11. században. Partes Populorum Minores Alienigenae [Szombathely] 6: 11-41.

ÚESz. = Új magyar etimológiai szótár. Főszerk. GERSTNER KÁROLY. [Szerkesztés alatt: http://uesz.nytud.hu] (2019. 07. 23.)

VARGA ÉVA KATALIN 2015. Anatómiai nevek névalkotása Apáczai Enciklopédiájában. In: FORGÁCS TAMÁS - NÉMETH MIKLÓS - SINKOVICS BALÁZS szerk., A nyelvtörténeti kutatások újabb eredményei 8. SZTE BTK Magyar Nyelvészeti Tanszék, Szeged. 201-212.

VERMES STEFÁNIA 1941. A magyar szókészlet etimológiai statisztikája. Nyelvtudományi Közlemények 51: 435.

WOHLFART ZOLTÁN 2018. Karácsonyi sólyomröptetés. Ösi Gyökér 36/3-4: 91-92.

ZOLTÁN, ANDRÁS 1986. О происхождении православного славянского слоя в венгерской христианской терминологии. Съпоставително езикознание 11/4: 5-9.

ZOLTÁNANDRÁs 1987. A hálát ad kifejezés eredetéről. In: GREGOR FERENC-NYOMÁRKAY ISTVÁN szerk., Szlavisztikai tanulmányok. Emlékkönyv Király Péter 70. születésnapjára. ELTE, Budapest. 427-437.

ZOLTÁn ANDRÁs 1991. Karácsony. In: HAJdú MiHÁLY - KISS JENÖ szerk., Emlékkönyv Benkö Loránd hetvenedik születésnapjára. ELTE, Budapest. 664-670. 
ZOLTÁN, ANDRÁS 1993. К вопросу о происхождении суффикса -ипъ (-ипь) в славянских языках: Studia Slavica Hungarica 38: 221-227.

ZOLTÁN ANDRÁs 2005a. Szavak, szólások, szövegek. Nyelvészeti és filológiai tanulmányok. Kisebbségkutatás Könyvek. Lucidus Kiadó, Budapest.

ZOLTÁN, ANDRÁS 2005b. Древнерусское слово корочюнъ и русский фразеологизм карачун ему пришел. In: ВАЛЬтЕР, Х. отв. ред., Грани слова. Сборник научных статей к 65-летию проф. В. М. Мокиенко. ЭЛПИС, Москва. 76-80.

ZOLTÁN, ANDRÁS 2015. Византийская миссия у венгров в Х в.: Вопрос о славянском языковом посредничестве. In: TAHIAOS, ANTHONY-EMIL ed., Cyril and Methodius.

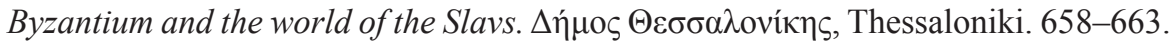

ZOLTÁN ANDRÁS 2016. A Kárpát-medencei szlávok nyelvéről a honfoglalás korában. In: É. KISS KATALIN - HEGEDÜS ATTILA - PINTÉR LILlA szerk., Nyelvelmélet és kontaktológia 3. Szent István Társulat, Budapest-Piliscsaba. 33-45.

ZOLTÁN ANDRÁS 2017a. Szláv jövevényszavaink néhány időrendi és nyelvföldrajzi kérdése. Magyar Nyelv 113: 1-9. https://doi.org/10.18349/magyarnyelv.2017.1.1

ZOLTÁN ANDRÁS 2017b. Régi keleti szláv jövevényszavaink kérdéséhez. In: LUKÁCS ISTVÁN szerk., Nexus Linguarum: Köszöntö kötet a 80 éves Nyomárkay István akadémikus tiszteletére. ELTE, Budapest. 377-384.

ZOLTÁN ANDRÁs 2018. A fog segédige szláv párhuzamai. In: DUDÁs MÁRIA - DUDÁs ELÖD szerk., Velencétől Dubrovnikig. Köszöntő kötet Vig István tiszteletére. ELTE, Budapest. 251-264.

ZOLTÁN, ANDRÁS - JANURIK, SZABOLCS 2018. Entlehnungen und Kalkierungen im Ungarischen. In: WitZlACK-MAKAREVICH, KAI Hrsg., Kalkierungs- und Entlehnungssprachen in der Slavia. Boris Unbegaun zum 120. Geburtstag. Frank \& Timme, Berlin. 325-338.

\section{Slavic elements of Byzantine rite in the Hungarian Christian terminology}

The 10th-century Byzantine conversion of Hungarians was carried out through Slavic mediation, as there were many Slavic-Hungarian bilinguals among the Hungarians settled in the midst of Slavic population, and Slavic-Greek bilingual missionaries were easy to find in the Balkan provinces of the Byzantine Empire (e.g. in Macedonia). Most of the early Slavic borrowings to Hungarian came from the Slavic substrate of the Carpathian Basin (Pannonian Slavic), and this is also true of Christian terminology. Due to the high degree of similarity between 10th-century Slavic dialects, it is difficult to separate terms locally borrowed from Pannonian Slavs from those introduced by the Byzantine missionaries speaking Slavic in Hungary. However, there are some words and expressions of Balkans origin (hálát ad 'give thanks', karácsony 'Christmas', pitvar 'porch', formerly 'limbo, edge of Hell', etc.) that could hardly have been found in Pannonian Slavic; these were most probably brought by the Byzantine missionaries and spread among the Hungarians.

Keywords: etymology, Slavic borrowings, Christian terminology, Byzantine mission. 